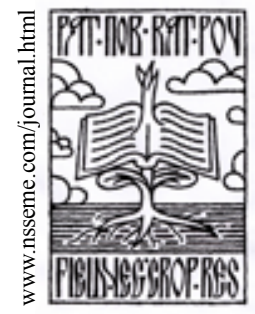

\title{
Resistance Evaluation of Different Inbreds and Hybrids of Sunflower To Broomrape (Orobanche cumana Wallr.)
}

\author{
Radovan Marinković • Milan Jocković • Ana Marjanović Jeromela • \\ Dragana Marisavljević • Zvonimir Sakač
}

\author{
received: 11 October 2013, accepted: 27 January 2014 \\ published online: 10 February 2014 \\ (c) 2013 IFVC \\ doi: $10.5937 /$ ratpov $50-4648$
}

\begin{abstract}
Summary: Resistance to broomrape of different inbred lines, hybrids and hybrid combinations of sunflower was investigated. The trial for this experiment, which was set at 6 locations on territory of Bačka, included set of differential genotypes which, according to literature, posess genes for resistance to races A-E, 152 inbred and 121 restorer lines developed at the Institute of Field and Vegetable Crops in Novi Sad, 72 crosses between these lines and 15 Russian and Ukrainian varieties. Differential genotypes behaved identically in all test sites. Domestic mother lines, restorer lines, newly developed hybrids as well as hybrid combinations showed resistance to present races of broomrape in all test sites in Vojvodina. Determination of resistance genes requires analysis of crossing inbred lines and differential lines. Results of the experiment performed in Romania and Turkey, with part of the experimental material, shows that these genotypes behaved differently in terms of resistance to broomrape in different conditions for experiments. The results require further separation on the basis of resistance to different races of the parasite by introducing new differential line.
\end{abstract}

Key words: broomrape, differentiation, genotyping, hybrids, inbred lines, inbreds, Orobanche cumana, races, resistance, sunflower

\section{Introduction}

In many countries, including Serbia, sunflower is the main oil plant. Sunflower oil has a special place among edible oils because of its quality. Because of this, the main goal of breeding is development of hybrids and varieties with high genetic potential for seed yield and oil content in seed. Among many factors causing yield reduction or total destruction of crop, broomrape is the most important one. At the beginning of growing sunflower as an oil plant in Russia, broomrape caused $100 \%$ plant damage. Today, it can cause $50 \%$ of yield loss (Dominguez 1996) and even more in some regions.

R. Marinković • M. Jocković* • A. Marjanović Jeromela • Z. Sakač Institute of Field and Vegetable Crops, 30 Maksima Gorkog, 21000 Novi Sad, Serbia

e-mail:milan.jockovic@nsseme.com

D. Marisavljević

Institute for Plant Protection and Environment, 9 Teodora Drajzera, 11000 Belgrade, Serbia
Orobanche is the largest genus among the holoparasitic members of Orobanchaceae (Young et al. 1999) and comprises approximately 170 species distributed predominantly in the Northern Hemisphere. The species from this family have been reported in the South-Eastern Europe (Bulgaria, Romania, former Yugoslavia, European part of Turkey), in Hungary, the Czech Republic, Slovakia, steppe zone of Ukraine, the Volga River valley, the area of the Caucasus, Asia Minor, Iraq, India, Tibet, Mongolia and countries of the Mediterranean basin (Italy, Egypt and Algeria) (Olangiu 1969, Škorić \& Jocić 2005, Mihaljčević 1996). Sacston (1978) writes about the presence of broomrape in Spain. By its spread and the extent of the damage caused to sunflower, broomrape (Orobanche cumana Wallr.) is the most important representative of the family Orobanchaceae.

\footnotetext{
Acknowledgements:

This study is a part of the research project no. TR-31025 titled Development of new varieties and production technology improvement of oil crops for different purposes, financed by the Ministry of Education, Science and Technological Development of the Republic of Serbia.
} 
Broomrape is a parasitic entomophily pollinated flowering weed without chlorophyll, which attacks the root system of sunflower plants by taking their water and minerals and therefore reduces the vitality of the affected plants, which in the end, depending on the severity of the attack, leads to partial or complete destruction of plants or crops. Therefore, one of the main objectives in the process of creating lines, hybrids and varieties is to introduce resistance to broomrape. Broomrape is obligate parasite and besides sunflower it also attacks tomatoes (Solanum bycopersicum), hop (Humulus lupulus), tobacco (Nicotiana tabaci), sugar beet (Beta vulgaris), carrot (Daucus carota), hemp (Cannabis sativa), alfalfa (Medicago sativa) and others.

In many countries around the world the appearance of one, two or three new races of the parasite has been recorded. In order to minimize damage to sunflower crops it is necessary to identify the genes for resistance to these races. Historically, sunflower breeders have been successful in developing broomrape resistant cultivars, but breeding programs are often based on a reduced number of dominant genes, while resistance breakdown caused by the appearance of new virulent races that overcome all known resistance genes has frequently occurred in the last decades (Fernández-Martínez et al. 2008). This situation has forced sunflower breeders to continuously search for new sources of resistance and/or using alternative methods of control such as the use of imidazolinone (IMI)-resistant hybrids. The aim of this review is to discuss recent advances in research in the development and genetic characterization of new sources of resistance to new virulent races, as well as in the biology and genetics of the parasite and in the development of IMI-resistant hybrids.

Due to the narrow genetic basis of cultivated sunflower for finding genes for the known races of the parasite research on wild sunflower species has been performed (Dozet \& Marinković 1998, Fernadez-Martinez et al. 2004, Jan 2004, Terzić et al. 2010).

Several methods have been proposed to control sunflower broomrape, including mechanical, biological, and chemical practices, but nowadays genetic resistance is regarded as the most effective, economically feasible and environmentally friendly solution (EchevarriaZomeno et al. 2006).

In order to find the most effective way of dealing with the creation of broomrape resistant sunflower hybrids and varieties, it is necessary to get to know the basic elements related to the biology of parasites, changes in the population structure of the parasite and selection strategies in the breeding process. However, the creation of resistant hybrids does not mean that there was a final victory due to the appearance of new, virulent races which under the same environmental conditions can parasitize host plant, mature normally and produce seeds.

Studying the genetics of resistance to broomrape Burlov and Kostyuk (1976) concluded that resistance is monogenic and inherited dominantly. The dominant resistance was also determined by Vranceanu (1980), Tolmachev (1986), Tsvetkova et al. (1998) and Petakov (1998). So at full resistance of hybrids it is enough that one of the parental lines is resistant to broomrape, and the second line can be characterized by some other good agronomic characteristics. According to Tolmachev (1986) dominance should not be viewed as a result of acts of appropriate genes in the genotype. This stems from the fact that expression of dominance can be changed under the influence of other genes that act as modifiers. It follows that for a study among allelic effects and explanations of degree of dominance it is necessary testing in different agro-ecological environments, which can be done by creating isogenic lines. Tsvetkova et al. (1998) and Petrov et al. (1980) supported this claim.

Before the election strategy in sunflower breeding for resistance to broomrape, racial composition should be determined, especially the identity of the new race. Vrancheanu et al. (1980) in Romania and Acimovic (1980) in Yugoslavia gave the most detailed study of genetic resistance to broomrape. While Vrancheanu et al. (1980) revealed the presence of five physiological races $(\mathrm{A}, \mathrm{B}, \mathrm{C}, \mathrm{D}, \mathrm{E})$ within the parasite population in the region Braila, Acimovic (1980) reports 7 noted physiological races within the parasite population in localities of the northern part of Vojvodina.

The aim of this study was to evaluate the resistance to broomrape of different inbred lines, hybrids and hybrid combinations of sunflower.

\section{Materials and Methods}

The experiment for this study, which was set up in six locations in the territory of Vojvodina, included a set of differential genotypes, which according to literature have genes for resistance to races $\mathrm{A}$ through $\mathrm{E}$ (Or-1... Or-5), 152 inbred 
and 121 restorer lines, as well as 72 crosses between these lines developed at the Institute of Field and Vegetable Crops Novi Sad, Serbia, and 15 Russian and Ukrainian varieties. In this paper we presented only the most promising genotypes selected on the basis of agronomically important traits, especially seed yield and oil content (unpublished data). Tested genotypes were sown by hand in three rows, and middle row was evaluated. This reduced the possibility of overlapping root systems between individuals and populations, and thus avoided the wrong grading. During the preparation of soil treflan was not used because its application reduces the number of plant parasite $30-60 \%$ (Vasilyev \& Baranova 1974, Aćimović 1978). The presence and number of broomrape plants per sunflower were determined visually when sunflower was in the blooming stage.

Independently of these genotypes, several domestic hybrids (Baca, Sremac, Nemanja and Jovan), two foreign hybrids and five promising hybrid combinations (UK-PA-45 $x$ RHA$B_{1}$, UK-PA-73x RHA-Z, U-1006 x RHA-Z, U-503 $\times$ RHA-B ${ }_{1}$ and NIL-23 $\times$ RHA-B B $_{1}$ were analysed in two localities in Romania (Tulcea and Cogealac). Also, only hybrid combinations were evaluated in the Agricultural Research Institute - Edirne, Turkey. Evaluation of the material in both localities in Romania was performed the same as in the localities in Vojvodina, while at the Institute - Edirne the method of Pancenko (1973) was used.

\section{Results and Discussion}

In addition to differential lines which showed sensitivity, all other analysed genotypes showed resistance in all observed localities in Vojvodina to the parasite complex (Table 1). Among the inbred lines one cms, three fertile analogues and three restorer lines showed resistance. However, given that in the set of differential genotypes those with resistance genes to races $F$ and $G$ (Melero-Vara \& Molinero 2004, FernandezMartinez et al. 2004) were not present, it cannot be stated with certainty that these lines have the gene or genes for resistance to these races.

This paper presents the results of an analysis of some promising hybrid combinations (Table 2). In Vojvodina, the values for the aforementioned quantitative traits were taken from the experiment set up at the Institute of Field and Vegetable Crops, Novi Sad, Serbia. Among the ten studied hybrids developed at Institute of Field and Vegetable Crops, four exhibited resistance and six showed sensitivity to the parasite complex in all observed localities. At the end, Table 2 shows testing results of some hybrid combinations for resistance to broomrape.

Among the promising hybrid combinations, the combination UK-PA-45 x B1 was found to have the lowest oil content $(45.78 \%)$, while combination UK-PA-229 $\times$ RH-Z had the highest oil content (49.15\%). Combination UK-PA-229 x B1 is characterized by the highest seed yield per unit area $(5.326 \mathrm{t} / \mathrm{ha})$. High seed yield was also found within combination UK-PA-229 x RH-17 (5.135 t/ha).

During the evaluation of resistance it has been observed that in all sunflower plants within one genotype, the same number of broomrape plants was not developed. The reason for this probably lies in the fact that the experiments were set up in different localities and soils do not contain the same amount of infective material. On the other hand, despite the high reproductive potential of broomrape, a significant number of broomrape seeds fail due to unfavourable weather conditions (high temperature and moisture content in the soil). Plant height and head diameter did not vary significantly by genotypes, regardless of the observed locality.

It is known that the weight of 1000 seeds is one of the three major components of seed yield. It is influenced by both genetic and environmental factors. Variability of the size of this property is specific to the different genotypes in one locality and one genotype in different localities. Besides, there is variability of this trait for genotypes among different circles in the head. Skoric (1989) and Marinković et al. (2003) argue that for the formation of high seed yield, value of 1000 seed weight should be over $80 \mathrm{~g}$. In this work among the studied hybrids the highest value for this property was expressed by Nikola $(75.10 \mathrm{~g})$ and the lowest by Milan $(60.00 \mathrm{~g})$. In this study the promising hybrid combinations of the highest value for the 1000 seed weight was found in UK-PA-229 x RH-Z (76.46 g) and the lowest in UK- PA-51 x RH-17 (57.11 g) and UK-PA-45 x RH-17 (57.66 g).

The collected data on the response of some genotypes on broomrape in localities in Vojvodina, Romania and Turkey are shown in Table 3. By observing the data, it can be noted that the analysed genotypes were resistant to the parasite complex in sites in the territory of Vojvodina, however some genotypes behaved differently in other localities. For example, in addition to the demonstrated resistivity in localities in Vojvodina, the genotype UK-PA-45 


\begin{tabular}{|c|c|c|c|c|c|c|c|c|}
\hline \multirow{8}{*}{ 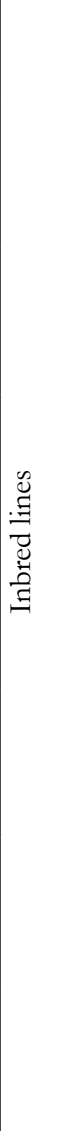 } & 岕至 & 光 & $\simeq$ & $\simeq$ & $\simeq$ & $\simeq$ & $\simeq$ & $\simeq$ \\
\hline & 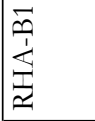 & ث̀ & $\simeq$ & $\simeq$ & $\simeq$ & $\simeq$ & $\simeq$ & $\simeq$ \\
\hline & 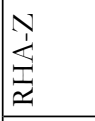 & O. & $\simeq$ & $\simeq$ & $\approx$ & $\approx$ & $\simeq$ & $\simeq$ \\
\hline & 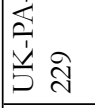 & تُ & $\simeq$ & $\simeq$ & $\approx$ & $\simeq$ & $\simeq$ & $\simeq$ \\
\hline & $\begin{array}{l}\frac{1}{\Delta} \\
\frac{1}{5} \\
\dot{5}\end{array}$ & ت. & $\simeq$ & $\simeq$ & $\simeq$ & $\simeq$ & $\simeq$ & $\simeq$ \\
\hline & 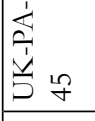 & ت. & $\simeq$ & $\simeq$ & $\simeq$ & $\simeq$ & $\simeq$ & $\simeq$ \\
\hline & 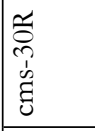 & ث. & $\simeq$ & $\simeq$ & $\simeq$ & $\simeq$ & $\simeq$ & $\simeq$ \\
\hline & $\begin{array}{l}\hat{D} \\
\hat{n} \\
\hat{1} \\
0\end{array}$ & $\stackrel{n}{0}$ & $\approx$ & $\simeq$ & $\simeq$ & $\simeq$ & $\simeq$ & $\simeq$ \\
\hline \multirow{5}{*}{ 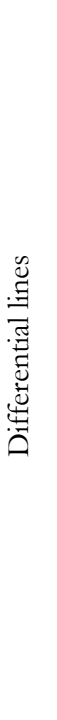 } & 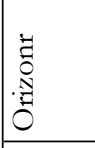 & ذँ & $\infty$ & is & $\infty$ & $\infty$ & is & $\infty$ \\
\hline & 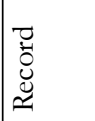 & $\stackrel{?}{3}$ & is & in & is & is & is & is \\
\hline & 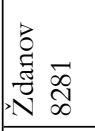 & $\begin{array}{l}\mathcal{1} \\
\stackrel{1}{0}\end{array}$ & is & is & in & is & is & n \\
\hline & 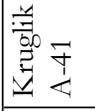 & I & $n$ & in & $\infty$ & $\infty$ & is & $\infty$ \\
\hline & $\begin{array}{l}0 \\
\stackrel{1}{1} \\
\stackrel{1}{\ell}\end{array}$ & 足 & is & in & $\infty$ & is & is & ns \\
\hline & 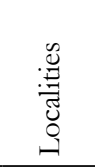 & & $\begin{array}{l}\frac{\pi}{0} \\
0 \\
0 \\
0 \\
0\end{array}$ & 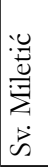 & 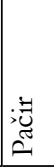 & 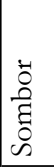 & 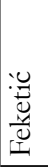 & 苨 \\
\hline
\end{tabular}


Table 2. Average characteristics of some hybrids and new hybrid combinations in Vojvodina

\begin{tabular}{|c|c|c|c|c|c|c|}
\hline Hybrids & $\begin{array}{c}\text { Resistance to } \\
\text { broomrape }\end{array}$ & $\begin{array}{l}\text { Plant height } \\
(\mathrm{cm})\end{array}$ & $\begin{array}{c}\text { Head } \\
\text { diameter } \\
(\mathrm{cm})\end{array}$ & $\begin{array}{l}1000 \text { seed } \\
\text { weight }(g)\end{array}$ & $\begin{array}{c}\text { Oil content } \\
(\%)\end{array}$ & $\begin{array}{l}\text { Seed yield } \\
\text { (t/ha) }\end{array}$ \\
\hline NS-H-45 & 0 & $160-170$ & 25 & 58.26 & 46.26 & 4.500 \\
\hline Krajišnik & 0 & $159-170$ & 25 & 65.38 & 49.70 & 4.368 \\
\hline Banaćanin & 0 & $165-180$ & 25 & 65.00 & 49.01 & 3.850 \\
\hline Bačvanin & 100 & $170-185$ & 25 & 64.46 & 49.15 & 3.740 \\
\hline Sremac & 100 & $170-175$ & 24 & 68.15 & 48.20 & 4.520 \\
\hline Baća & 100 & 180185 & 25 & 70.10 & 48.10 & 4.050 \\
\hline Nikola & 100 & $160-180$ & 25 & 75.10 & 50.25 & 4.275 \\
\hline Vladimir & 100 & $160-170$ & 25 & 63.10 & 48.45 & 4.385 \\
\hline Milan & 100 & $160-180$ & 25 & 60.00 & 48.83 & 4.680 \\
\hline Cms 30R x RH-17 & 100 & $160-170$ & 24 & 73.64 & 48.15 & 4.597 \\
\hline $\begin{array}{l}\text { UK-PA-45 x RH- } \\
17\end{array}$ & 100 & $170-180$ & 24 & 57.66 & 47.66 & 4.683 \\
\hline $\begin{array}{l}\text { UK-PA-51 x RH- } \\
17\end{array}$ & 100 & $170-180$ & 25 & 57.11 & 46.57 & 4.695 \\
\hline $\begin{array}{l}\text { UK-PA-229 x RH- } \\
17\end{array}$ & 100 & $180-190$ & 24 & 60.80 & 48.06 & 5.135 \\
\hline Cms 30R x RH-Z & 100 & $160-170$ & 25 & 57.36 & 47.57 & 4.210 \\
\hline $\begin{array}{ll}\text { UK-PA-45 } & x \\
\text { RH-Z } & \end{array}$ & 100 & $170-180$ & 25 & 72.73 & 47.39 & 4.093 \\
\hline $\begin{array}{ll}\text { UK-PA-51 } & x \\
\text { RH-Z } & \end{array}$ & 100 & $170-180$ & 23 & 73.34 & 47.84 & 4.677 \\
\hline $\begin{array}{ll}\text { UK-PA-229 } & x \\
\text { RH-Z } & \end{array}$ & 100 & $170-175$ & 24 & 76.46 & 49.15 & 4.780 \\
\hline Cms $30 \mathrm{R}$ x RH-B & 100 & $180-185$ & 23 & 65.32 & 45.63 & 4.433 \\
\hline UK-PA-45 × B & 100 & $160-170$ & 23 & 63.09 & 45.40 & 4.139 \\
\hline UK-PA-51 × $\mathrm{B}_{1}$ & 100 & $170-180$ & 24 & 59.51 & 46.26 & 4.250 \\
\hline UK-PA-229 x B & 100 & $165-185$ & 23 & 65.21 & 45.78 & 5.326 \\
\hline
\end{tabular}

$x$ RHA-B1 expressed different reaction in the locality Cogealac (Romania) in two replicates. In the first replicate presence of broomrape was not recorded, while in the second it was. Under laboratory conditions at the Agricultural Research Institute - Edirne Turkey, broomrape was absent in both replicates. However, in Tulcea locality broomrape was present with low abundance on plants in the first replicate, while in the second attendance was higher. The genotypes U- 503 $x$ RHA-B1 and NIL 23 x RHA-B1 behaved similarly. On genotype UK-PA-73 x RHA-Z, site
Tulcea in both replicates at all plants, presence of the parasite was with low abundance. In Cogealac locality on plants in the first replicate presence of broomrape with low abundance was noted, while in the second replicate of 20 sunflower plants only one showed the presence of the parasite. In the Institute of Edirne the presence of the parasite was recorded on the plants in the second replicate. All this supports the opinion of Škoric \& Jocic (2005) that in some countries the racial composition of the parasite is not completely clear. 
Table 3. Broomrape presence on some genotypes

\begin{tabular}{|c|c|c|c|c|c|c|c|c|c|c|c|}
\hline \multirow[b]{2}{*}{ Genotype } & \multirow[b]{2}{*}{ Repl. } & \multicolumn{10}{|c|}{ Locality } \\
\hline & & $\begin{array}{c}\text { Bač. } \\
\text { Topola }\end{array}$ & $\begin{array}{c}\text { Sv. } \\
\text { Miletić }\end{array}$ & Pačir & Sombor & Feketić & Lipar & Šupljak & $\begin{array}{c}\text { Tulcea- } \\
\text { Ru }\end{array}$ & $\begin{array}{c}\text { Cogealac- } \\
\mathrm{Ru}\end{array}$ & $\begin{array}{c}\text { Institute- } \\
\text { Edirne }\end{array}$ \\
\hline \multirow{2}{*}{ NS-H-Baća } & $\mathrm{I}$ & - & - & - & - & - & - & - & ++ & + & 1 \\
\hline & II & - & - & - & - & - & - & - & ++ & $4 / 18$ & l \\
\hline \multirow{2}{*}{$\begin{array}{l}\text { NS-H- } \\
\text { Sremac }\end{array}$} & I & - & - & - & - & - & - & - & + & + & I \\
\hline & II & - & - & - & - & - & - & - & + & $5 / 18$ & I \\
\hline \multirow{2}{*}{$\begin{array}{l}\text { NS-H- } \\
\text { Nemanja }\end{array}$} & $\mathrm{I}$ & - & - & - & - & - & - & - & - & + & 1 \\
\hline & II & - & - & - & - & - & - & - & + & $2 / 19$ & 1 \\
\hline \multirow{2}{*}{ NS-H-Jovan } & $\mathrm{I}$ & - & - & - & - & - & - & - & + & - & 1 \\
\hline & II & - & - & - & - & - & - & - & + & + & 1 \\
\hline \multirow{2}{*}{ LG 6556} & I & - & - & - & - & - & - & - & + & & I \\
\hline & II & - & - & - & - & - & - & - & + & & l \\
\hline \multirow{2}{*}{ PR 64G64 } & I & - & - & - & - & - & - & - & + & & 1 \\
\hline & II & - & - & - & - & - & - & - & ++ & & l \\
\hline \multirow{2}{*}{$\begin{array}{l}\text { UK-PA-45 x } \\
\text { RHA-B1 }\end{array}$} & I & - & - & - & - & - & - & - & & - & - \\
\hline & II & - & - & - & - & - & - & - & & + & - \\
\hline \multirow{2}{*}{$\begin{array}{c}\text { UK-PA-73 x } \\
\text { RHA-Z }\end{array}$} & I & - & - & - & - & - & - & - & & + & - \\
\hline & II & - & - & - & - & - & - & - & & $1 / 19$ & $1 / 20$ \\
\hline \multirow{2}{*}{$\begin{array}{c}\text { U- } 1006 x \\
\text { RHA-Z }\end{array}$} & $\mathrm{I}$ & - & - & - & - & - & - & - & & + & - \\
\hline & II & - & - & - & - & - & - & - & & + & - \\
\hline \multirow{2}{*}{$\begin{array}{l}\text { U-503 x } \\
\text { RHA-B }\end{array}$} & $\mathrm{I}$ & - & - & - & - & - & - & - & & - & - \\
\hline & II & - & - & - & - & - & - & - & & & - \\
\hline \multirow{2}{*}{$\begin{array}{l}\text { NIL-23 x } \\
\text { RHA-B }\end{array}$} & $\mathrm{I}$ & - & - & - & - & - & - & - & + & & - \\
\hline & II & - & - & - & - & - & - & - & ++ & & - \\
\hline
\end{tabular}

- broomrape not present; + broomrape present on every plant with low abundance; ++ severe attack of broomrape with over 20 plants per sunflower plant; / no data

\section{Conclusions}

Genotypes showed different degrees of resistance depending on the tested sites (Vojvodina, Romania, Turkey) which can be explained by the different racial composition of the parasite. According to literature data, it has been shown that there is a change in the racial composition of the population of $O$. cumana. The most promising hybrid combinations for the territory of Vojvodina are UK-PA-229 x RH-Z and UK-PA-229 $\mathrm{B}$ B1 because in addition to the demonstrated complete resistance to broomrape these were characterized by the highest oil content in the seed, i.e. the highest seed yield per unit area.

\section{References}

Aćimović, M. (1977). Distribution of important sunflower diseases in Yugoslavia. Novi Sad: Faculty of Agriculture, Institute of Field and Vegetable Crops. 1-16.

Aćimović, M. (1978). Possibility to control Orobanche cumana Wallr. sunflowers by Treflan and Amex. In: Int. Sunflower Conference (8th), July 23- 27, Minneapolis, Minnesota, USA. 237-240.

Aćimović, M. (1980). Physiological race of Orobanche cumana Wallr. on sunflower in Yugoslavia. In: Int. Sunflower Conference (9th), June 8-13, Torremolinos, Spain. 162-166.

Bošković, M. (1962). Vodnjača suncokreta. Zbornik Matice srpske za prirodne nauke, 22,

Burlov, V.V., \& Kostyuk, S.V. (1976). Inheritance of the resistance to the local race of the broomrape (Orobanche cumana Wallr.) in sunflower. Genetika (Moskow), 12, 44-51.

Dominguez, J. (1996). Estimating effects on yield and other agronomic parameters in sunflower hybrids infested with the new races of sunflower broomrape. In: Symposium on disease tolerance in sunflower, Beijing, China. Paris: International Sunflower Association.118-123.

Dozet, B., \& Marinković, R. (1998). Resistance of wild Helianthus annuus L. and Helianthus petiolaris ssp. petiolaris to broomrape (Orobanche cumana Wallr). In: 2nd Balkan Symposium on Field Crops, 16-20. Jun, Novi Sad. 161-164. 
Echevarria-Zomeno, S., Perez-Luque, A., Jorrin, J., \& Maldonado, A. (2006). Pre-haustorial resistance to broomrape (Orobanche cumana) in sunflower (Helianthus annuus): Cytochemical studies.J Exp Bot, 57, 4189-4200.

Fernández-Martínez, J.M., Velasco, L., \& Pérez-Vich, V.B. (2004). Resistance to the new highly virulent races of sunflower broomrape (Orobanche cumana Wallr.): Sources of variation and genetic studies. In: COST Action 849, Parasitic Plant Management in sustainable Agriculture, 4-6 November, Bucharest, Romania. 2.

Fernández-Martínez, J.M., Velasco, L., \& Pérez-Vich, V.B. (2008). Progress in research on breeding for resistance to broomrape. (pp. 1-6). Córdoba, Spain: Instituto de Agricultura Sostenible (CSIC). Alameda del Obispo s/n. E-14004.

Jan, C.C. (2004). Developing germplasm pools having wild $\mathrm{He}$ lianthus genes in domestic background. In: COST Action849, Parasitic Plant Management in sustainable Agriculture, 4-6 November, Bucharest, Romania. 2.

Marinković, R., Dozet, B., \& Vasić, D. (2003). Oplemenjivanje suncokreta. Novi Sad: Školska knjiga. Monografija.

Mihaljčević, M. (1996). Volovod (Orobanche cumana Wallr.) na suncokretu - promene u populaciji. Zbornik radova Instituta $z$ a ratarstvo i povrtarstvo, Novi Sad, 25, 59-71.

Melero-Vara, J., \& Molinero, L.R. (2004). Race differantiation of Orobache cumana in Spain. In: COST Action849, Parasitic Plant Management in sustainable Agriculture, 4-6 November, Bucharest, Romania. 12.

Olangiu, M. (1969). Tratat de fitopatologie Agricola. Edit Acad, 2, 228-242.

Pancenko, A.N. (1973). Rannija diagnostika zarazihoustoicivosti ori selekcii podsolnecnika. In Zbirnik VNIIMK. (pp. $107-$ 115).

Petakov, D.P., Shindrova, P., Nenov, N., \& Christov, M. (1998). Combining ability of new sunflower lines that are resistant to broomrape. In: Proc. of the 4th International Orobanche workshop, 23-26 September, Albena, Bulgaria. 307-312.
Petrov, P., Shindruvap, P., \& Panchev, E. (1980). Effect of Helianthus petiolaris cytoplasm on resistance to bromrape. Plant Breeding Abstracts, 56, 10622

Sacston, W.E. (1978). Sunflower desease mapping in Europe and adocent mediterranein countries. In: Proc. of the 8th Inter. Sunf. Conf. 23-27 July, Minneapolis, Minesota USA. 7-29.

Škorić, D. (1989). Dostignuća i dalji pravci u oplemenjivanju suncokreta. In D. Škorić (Ed.), Suncokret. (pp. 285-392). Beograd: Nolit.

Škorić, D., \& Jocić, S. (2005). Volovod (Orobanche cumana Wallr.) i mogućnost njegovog suzbijanja genetskim i hemijskim putem. In: Proizvodnja i prerada uljarica, Savetovanje industrije ulja (46), Petrovac na Moru. 06-10.06. 2005. 9-20.

Terzić, S., Dedić, B., Atlagić, J., Jocić, S., \& Tančić, S. (2010). Screening wild sunflower species and F1 interspecific hybrids for resistance to broomrape. Helia, 33(53), 25-30. doi:10.2298/ HEL1053025T

Tolmačev, V.V. (1986). Stepen dominirovanija gena zarazihustoćivosti i jego nasledovanije s markernimi priznakami podsolnečnika. Naučnu tehničenskij bjulten vsvesajuznogo naučnoissledovateljsogo instituta masljičnih kuljtur, 2(93), 3-6.

Tsvetkova, F., Nenov, N., \& Shindrova, P. (1998). Breeding of fertility restorer lines resistance. In: 4th International Orobanche workshop, 23-26 September, Albena, Bulgaria. 313-316.

Vasiljev, D.S., \& Baranova, L.A. (1974). Treflan protiv zarazihi na podsolnečniku. Bjulten naučno-tehničeskoj informacii po masličnh kuljturam VNIIMK, Krasnodar, 111, 47-49.

Vranceanu, A.V., Tudor, V.A., Stoenescu, F.M., \& Pirvu, N. (1980). Virulence groups of Orobanche cumana Wallr., differential hosts and resistance source genes in sunflower. In: Int. Sunflower Conference (9th), June 8-13, Torremolinos, Spain. Paris: Int. Sunflower Association.74-82.

Young, N.D., Steiner, K.E., \& Depamphilis, C.W. (1999). The Evolution of Parasitism in Scrophulariaceae/Orobanchaceae: Plastid Gene Sequences Refute an Evolutionary Transition Series. Annals of the Missouri Botanical Garden, 86(4), 876-893. doi: $10.2307 / 2666173$

\title{
Procena otpornosti različitih inbred linija i hibrida suncokreta na volovod (Orobanche cumana Wallr.)
}

\author{
Radovan Marinković • Milan Jocković • Ana Marjanović Jeromela • \\ Dragana Marisavljević • Zvonimir Sakač
}

Sažetak: Ispitivana je otpornost na volovod različitih inbred linija, hibrida i hibridnih kombinacija suncokreta. Ogled za ovaj eksperiment, koji je postavljen na 6 lokacija na teritoriji Bačke, uključio je set diferencijalnih genotipova koji, prema literaturi, imaju gene za otpornost prema rasama A-E, 152 i 121 samooplodne restorer linije stvorene u Institutu za ratarstvo i povrtarstvo, Novi Sad, 72 ukrštanja ovih linija i 15 ruskih i ukrajinskih sorti. Diferencijalni genotipovi su se ponašali identično u svim ispitivanim lokacijama. Domaće linije majke, restorer linije, novorazvijeni hibridi, kao i hibridne kombinacije su pokazali otpornost na prisutne rase volovoda u svim ispitivanim lokacijama na teritoriji Vojvodine. Određivanje gena otpornosti zahteva analizu ukrštanja inbred linija i diferencijalnih linija. Rezultati ogleda izvedenog u Rumuniji i Turskoj sa delom eksperimentalnog materijala pokazuju da su se ovi genotipovi različito ponašali u pogledu otpornosti na volovod u različitim uslovima izvođenja ogleda. Rezultati nalažu dalje razdvajanje na osnovu otpornosti na različite rase volovoda uvođenjem novih diferencijalnih linija.

Ključne reči: diferencijacija, genotipizacija, hibrid, inbred linije, Orobanche cumana, otpornost, rase, suncokret, volovod 